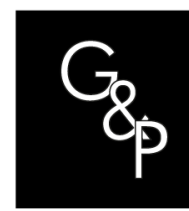

\title{
Opportunistic behavior in public bidding of agricultural products in IFSULDEMINAS - Campus Inconfidentes
}

\section{Comportamento oportunístico em licitações públicas de produtos agropecuários no IFSULDEMINAS - Campus Inconfidentes}

\author{
Lucas Deleon Ramirio' ${ }^{10}$, Wagner Roberto Pereira² ${ }^{2}$, Juciara Nunes de Alcântara ${ }^{3}$ \\ ${ }^{1}$ Instituto Federal de Educação, Ciência e Tecnologia do Sul de Minas Gerais - IFSULDEMINAS, Campus \\ Muzambinho, Departamento de Segurança do Trabalho, Muzambinho, MG, Brasil. E-mail: \\ lucas.ramirio@ifsuldeminas.edu.br \\ ${ }^{2}$ Instituto Federal de Educação, Ciência e Tecnologia do Sul de Minas Gerais - IFSULDEMINAS, Campus \\ Inconfidentes, Departamento de Administração e Planejamento, Inconfidentes, MG, Brasil. E-mail: \\ wagner.pereira@ifsuldeminas.edu.br \\ ${ }^{3}$ Universidade Federal de Lavras - UFLA, Departamento de Administração e Economia, Lavras, MG, Brasil. E-mail: \\ juciara.alcantara@ufla.br
}

How to cite: Ramirio, L. D., Pereira, W. R., \& Alcântara, J. N. (2021). Opportunistic behavior in public bidding of agricultural products in IFSULDEMINAS - Campus Inconfidentes. Gestão \& Produção, 28(1), e4832. https://doi.org/10.1590/1806-9649.2020v28e4832

\begin{abstract}
This study is based on the theory of transaction costs (TCT) to analyze the opportunistic behavior of suppliers in public purchases of agricultural products provided by the private sector. We argue that among the public purchasing modalities, the electronic auction, although using the principles of the reverse English auction and considered as a market structure governance driven by price, presents opportunistic behavior at the time of bidding by the seller, until the closing of the contract with the buyer. We analyzed the differences in price quotations and the closing price of 20 agricultural products purchased in electronic auction of public bidding processes in comparison to the bid prices and of references between the years 2014 to 2017 in the Federal Institute Sul de Minas - Campus Inconfidentes. The results show that there was a discount in the biddings between the years 2014 and 2017, since the repetition of bids in electronic auction forced the reduction of prices by the suppliers. However, it was possible to note opportunism by some agents, in the items in which the public agency under study did not fully specify the bidding product.
\end{abstract}

Keywords: Opportunism; Limited rationality; Electronic bidding.

Resumo: Este trabalho se fundamenta na teoria dos custos de transação (TCT) para analisar o comportamento oportunístico dos fornecedores em compras públicas de produtos agropecuários fornecidos pelo setor privado. Argumenta-se que dentre as modalidades de compras públicas, o pregão eletrônico, embora utilize os princípios do leilão inglês reverso e seja considerado como uma estrutura de mercado regida pelo preço, apresenta comportamentos oportunísticos no momento do lance pelo vendedor, até o fechamento do contrato com o comprador. Foram analisadas as diferenças de cotações de preços e do preço de fechamento de 20 produtos agropecuários adquiridos em pregão eletrônico de processos de licitação pública em comparação aos preços licitados e de referências entre os anos de 2014 a 2017 no Instituto

Received May 11, 2019 - Accepted Oct. 14, 2019

Financial support: None.

This is an Open Access article distributed under the terms of the Creative Commons Attribution License, which permits unrestricted use, distribution, and reproduction in any medium, provided the original work is properly cited. 
Federal Sul de Minas - Campus Inconfidentes. Os resultados permitem verificar que ocorreu um desconto nas licitações entre os anos de 2014 e 2017, visto que a repetição de lances em pregões forçou a redução de preços por parte dos fornecedores. Todavia, foi possível constatar oportunismos por parte de alguns agentes, nos itens em que o órgão público em estudo não especificou de forma completa o produto licitado.

Palavras-chave: Oportunismo; Racionalidade limitada; Pregão eletrônico.

\section{Introduction}

Transaction costs notion was first mentions in seminal contributions by Ronald Coase in his article "The Nature of the firm" from 1937, as a result of his effort to integrate institutional elements of the capitalist economy into traditional economic theory (Sarto \& Almeida, 2015).

According to Williamson (1985) the transaction costs theory is supported by two pillars: limited rationality of economic agents and opportunism in the actions of economic agents. The first is related to the limits of human cognitive competence; and the second refers to self-interested with the individuals' eagerness. The limited rationality when we cannot anticipate all future situations exposes the transactions to opportunistic behavior.

In this sense, the presence of opportunism and limited rationality can generate transaction costs, which may be minimized by choosing a governance structure that best adjusts the specificities of the transacted asset (Williamson, 1985). Thus, contractions with remnants of limited rationality generate opportunism from the suppliers (Zylbersztajn, 2005).

Among governance structures, Williamson (1985) points out that transactions through the market mechanism are characterized by the existence of a large number of asset transactions of little specificity, without the transaction establishes any kind of dependency relationship among agents, such as the electronic auction. According to Padilha et al. (2018), the electronic auction system differs from other public procurement modalities by judging and contracting the proposals that present the best prices.

According to Izaac \& Biderman (2005), the most common form of auctions is called an "English auction" in which the auctioneer starts from a reserve price (lower price in which the seller will dispose of the good) and the participants offer higher prices, usually varying by a minimum increment, until no participant gives a new bid, winning the one that presented the highest bid.

One of the most important instruments taken to establish and guarantee trade in the economy is the contract where the obligations of the parties are stipulated. They also establish the contingencies and interests involved as well as the safeguards to minimize the risks inherent to the contractual relationship (Nóbrega, 2009).

Although it is a governance structure via market, some studies have shown the presence of risks and uncertainties in the buying process via electronic auction, such as in Padilha et al. (2018) and Faria et al. (2013). Thus, this study aims to contribute to the discussion, emphasizing opportunistic behavior by suppliers in a market mechanism system used for public purchases of agricultural products.

The IFSULMINAS - Inconfidentes is suitable for the development of this study, since being a public educational institution, it uses of electronic auctions for the purchase of agricultural products to maintain the largest farm school institution. The purchase of the institution through Electronic Auction between 2014 and 2017 had an estimated 
amount of approximately $R \$ 262$ thousand reais and of $R \$ 3.6$ million reais respectively for the purchase of fertilizers and seeds, and for rations and supplements through the reverse auction mechanism, where the dispute over contracts is based on the interaction between the suppliers that send decreasing bids through the Government Purchasing Portal website.

Thus, the objective of this article was to analyze the opportunistic behavior of suppliers in electronic auction systems in the price system of agricultural products between the public and private sector, with support in the theory of transaction costs evidencing the opportunism and limited rationality of the public sector in these processes.

The results of this study contribute to the public managers since it points out possible gaps in the bidding process that allow opportunistic actions of the suppliers, which may cause the prices of the contracting products to be higher than the prices prevailing in the market, generating transaction costs. In addition, the results obtained may also benefit the institute, since it demonstrates the possibility of reducing transaction costs on purchases by bidding, which can reduce the costs of agroindustrial products produced and marketed by the institution itself.

\section{Theoretical referential}

\subsection{Transaction costs}

According to Fiani (2013) until the publication of the article 'The Nature of the Firm', the economic theory dealt in detail only the costs of production. Although we recognized the existence of transaction costs in the strict sense that not only the act of producing, but also the act of buying and selling demanded costs, it is generally assumed that the costs associated with economic transactions were negligible, so the only costs that really mattered were the costs of production.

Transaction costs are the costs that result from the division of labor, that is, the division of tasks into the productive process. Thus, agents face transaction costs whenever they turn to the market to acquire what is necessary for the production of a good or service (Hasenclever \& Kupfer, 2012). This has led some theorists of transaction cost, such as Ronald Coase, to identify transaction costs as costs of resorting to the market. In this approach, transaction costs are the costs of negotiating, drafting, and enforcing a contract, and the analysis basic unit when dealing with transaction costs would be the contract (Fiani, 2013).

For Lopes (2017) the theory of transaction costs is crucial for the decision-making process, since the institutions are permeable internally and externally, due to the exchange relations among economic agents. In an environment where a strong degree of specialization and a division of rational labor are required in which the transaction is the central point, the reduction of the transaction encourages cooperation and attenuates opportunism, increasing production mechanisms efficiently (Schlabitz, 2008).

To better understand how the discussion about transaction costs occurs in public sector organizations, according to Peres (2007) it is necessary to map the relevant actors for the transactions, the existing costs, and some characteristics of the public authority organizations. According to the author as actors we can cite executive power, legislative, bureaucracy that constituted in the managing body of the state apparatus 
for the execution of public policies, and civil society. With regard to transaction costs in the public sector Peres (2007) lists some of the most relevant ones based on Horn's (2002) analysis:

a) a first transaction cost is associated with the time and effort expended by politicians, both from the Executive and Legislative, in seeking agreement on a given public policy. The existence of conflict and uncertainty increases the defining cost of clear and precise rules and tends to promote laws and vague public policies. This vagueness, in turn, brings other problems to be balanced, because the benefits created by such laws and policies are not clear, making it difficult to verify the objectives meeting;

b) another transaction cost lies in the fact that the duration of benefits proposed by a public policy is affected by long-term commitment issues, due to greater or lesser ability of legislators and executives to change, amend, and replace laws and rules. In a democracy, there is no guarantee that a change of legislature will not lead to a revision of the rules of a particular public policy;

c) another cost may come from the fact that the Executive, the Legislative, the bureaucracy and civil society do not necessarily have the same understanding, commitment and energy to program, manage, monitor and evaluate public policies, so the benefits of a specific policy may not materialize. This implies an agency cost, especially between Executive Power and bureaucracy;

d) the monitoring cost of bureaucracy can be seen within a main-agent model, which we could analyze in two ways. The first way relates the objectives of the main actor, the politician, and the objectives and motivations of the subordinate actor, to bureaucracy. In this first model, there must be a design of governance structure where the main actor can control the agent in order to execute his objectives, that is, the implementation of public policies as they were conceived in their government, and for this it will be necessary to use an incentive system that allows this induction;

e) a last type of transaction cost, related here, exists due to the lack of clarity on the part of the civil society, regarding the private benefits or costs associated with a given public policy. This lack of clarity is higher when financing a policy takes place entirely due to the payment of taxes, (Transaction Costs and Governance Structure in the Public Sector RBGN, São Paulo, Vol. 9, n.24, pp. 15-30, May / Aug 2007 23) whose burden falls on a large part of society in a non-individualized way. Under these circumstances, the support for a given public policy will depend on the citizen's risk aversion: the greater the risk, the less likely to support new policies (Horn, 2002).

Ursula Peres highlighted several factors that interfere with the transaction cost for the government, especially those related to the creation, execution, monitoring and evaluation of public policies.

\subsection{Auctions theory}

According to Izaac \& Biderman (2005) an auction is a market institution with an explicit set of rules, determining the allocation of resources and prices based on bids from market participants. Yet according to the authors, the auctions represent a pricing mechanism in which an offeror seeks to extract the entire reserve price of a plaintiff. 
When analyzing an auction procedure is evident the participation of three main actors: organizer, seller and buyer.

The essential feature of the English auction is that at any point in time each participant knows the highest bid up to that point. In government purchases, the model called the reverse English auction is adopted, according to Izaac \& Biderman (2005) this model reverses the role of buyer and seller, that is, the buyer manifests the need for a good and the sellers make offers to meet this demand.

According to Menezes et al (2007) auctions can be considered secular institutions used in commercial relations between individuals and organizations, generating greater flexibility in the processes of price determination and allocation of goods, increasing the space for buyers and sellers to negotiate. In the purchases made by the institution under study the modality of Electronic Auction bidding adopts this mechanism of reverse auction, where the contract dispute is based on the interaction between the suppliers that send decreasing bids through the Government Procurement Portal website.

According to Menezes et al. (2007) considering a reverse auction RA, with maximum price $p_{\max }$ and minimum decrease $\delta_{R A}$, previously defined by the buying organization, only bids $b_{i} \leq p_{\max }-\delta_{R A}, i=1 \ldots n$ participants can be accepted. For each accepted bid, the new maximum price $p_{\max }=b_{i}$ is calculated and a new round starts, with the submission of new bids, by the participants. The auction finishes when no new offers are observed during a pre-established time interval, or when the time limit for its completion expires. In such cases, the right to market the good or service is ensured to the supplier who submitted the lowest bid, $b_{i}=p_{\max }$.

McAfee \& McMillan (1987, p. 711) show that increasing the number of participants in the auction improves the average result for the auctioneer, in practice we observe that more suppliers participate in a certain electronic auction session, the competition encourages the successive offer of decreasing bids, which guarantees a lower price paid on average.

In the case of this study is analyzed the purchasing process of a federal public educational institution, which adopts the electronic auction system as a mode of acquiring, in which case the institution assumes two functions simultaneously: buyer and organizer.

\subsection{Public purchase: electronic auction}

The Law n. ${ }^{\circ} 10.520$, of July 17,2002 , established, within the scope of the Union, States, Federal District and Municipalities, a bidding modality, called trading. Article 4, paragraph 1, of Decree n. ${ }^{\circ} 5.450$, dated May 31, 2005, regulates and makes mandatory the use of the trading in electronic form, for the acquisition of common goods and services, except in cases of proven impossibility to be justified by the competent authority. This type of bidding, destined to the acquisition of common goods and services, has as important characteristic the speed in the bidding processes, minimizing costs for the Public Administration and consolidated as the main form of contracting of the Federal Government (Brasil, 2002).

According to Braga (2006) the main objectives of this type of bidding is an entrepreneurial management focused on: 1. reduce the purchase time cycle; 2. increase efficiency, through reduction of operating costs and transaction costs; 3. improve communication channels through the Government Procurement Portal - 
Comprasnet; 4. improvement of internal processes, with the use of information systems due to their agility.

For Menezes et al. (2007) when it uses information technology resources, this modality is called Electronic Auction, which, in the scope of the Federal Public Administration, including the three Powers, is carried out through the Government Procurement Portal - Comprasnet, thus enabling the participation of a larger number of geographically dispersed suppliers. The electronic auction is the bidding modality that presents the greatest set of positive points for the public administration, noteworthy significant increases in the number of suppliers and consequently greater reduction in price (Vasconcelos, 2005).

According to Oliveira \& Santos (2016), the bureaucracy of Law 8.666/1993 (Brasil, 1993) sought to limit the degree of decision of the public agent, thus minimizing their opportunistic behavior, however the theory of transaction costs presupposes the limited rationality of individuals, the incompleteness of information and the presence of opportunism.

\subsection{Administrative contracts}

According to Law 8666/93 (Brasil, 1993), the administrative contracts referred to this Law are governed by their clauses and by the public law principles, complementarily applying the principles of general contractual theory and provisions of private law. The contracts must establish clearly and precisely the conditions for their execution, expressed in clauses defining the rights, obligations and responsibilities of the parties, in accordance with the terms of the bid and the proposal to which they relate.

For Nóbrega (2009), the classic contract model assumes that the parties present unlimited rationality and process optimally all the information they receive. There is, therefore, information freely and fully intelligible by the parties when signing the agreement, which determines the absence of cognitive difficulties. In addition, the parties are concerned with maximizing their utility functions, not worried about cheating or taking advantage of privileged information. Finally, in the classical synthesis, the exchanges are made at zero cost, which imposes a strict rationality in the contractual elaboration.

The contracts and their additions shall be drawn up at the concerned offices, which shall keep a chronological record of their autographs and systematic record of their extract, except those relating to real rights about properties, which are formalized by an instrument drawn up in a notary's office, all of which shall be accompanied by a copy in the proceedings that gave rise to it. The contracts governed by this Law may be changed, if properly justified.

All contracts must be faithfully fulfilled by all parties, following the existing clauses. The total or partial non-execution of the contract will result in rescission, with contractual consequences (Brasil, 1993).

The contract is only essential, according to art. 62 of Law $n^{\circ} 8.666 / 93$, in the case of competition, pricing, exemptions and inexibility, provided that the prices are comprised within the limits of these two modalities of bidding.

After the dispute has arisen among the companies interested in providing a certain service or selling a certain product to the Public Administration, and after deciding possible resources, it is up to the winner to sign a contract with the Public Power. However, not always the winner will sign a contract, since this instrument can be replaced by other skillful instruments, such as record of price, expense commitment note, purchase authorization or service execution order (Lamarão, 2011). 
However, the public purchase, in addition to the contract itself, requires a bidding process that precedes it. This imposes some additional elements that also encumber the transaction (Herrmann, 1999). Thus, we could describe the transaction costs of the bidding process as the summation:

$X$ the costs of designing, negotiating and providing for contractual safeguards (exante transaction costs), henceforth TCac;

$X$ the costs of monitoring and controlling the contract (ex-post transaction costs); henceforth TCpc;

$X$ the costs associated with the execution of the bidding, which include: the cost of preparing and publishing the public notice, realization of qualification and evaluation of the proposal, publication of the winners, and the costs associated with the time elapsed between the need to purchase and receiving the product, henceforth TCbid.

\section{Methodology}

This research consists of a case study, with quantitative data, collected through the values of purchases of agricultural products acquired by IFSULDEMINAS - Campus Inconfidentes in the period from 2014 to 2017, accessed in Comprasnet portal of the federal government.

The logic of the bidding, is the acquisition by the "lowest price". Thus, the public administration gathers suppliers by establishing a concurrence that will allow them to acquire goods at prices lower than those that would be practiced in the absence of this competition. If this is true, and the bidding is an efficient instrument, then:

$T C a c+T C p c+T C b i d+P b i d \leq P m$

where:

TCac $=$ the costs of designing, negotiating and providing for contractual safeguards (ex-ante transaction costs);

$\mathrm{TCpc}=$ the costs of monitoring and controlling the contract (ex-post transaction costs); TCbid $=$ the costs associated with the execution of the bidding, which include: the cost of preparing and publishing the public notice, realization of qualification and evaluation of the proposal, publication of the winners, and the costs associated with the time elapsed between the need to purchase and receiving the product;

Pbid $=$ product price offered by the winning bidder supplier;

$\mathrm{Pm}=$ product price on the market.

Due to the great difficulty in measuring the transaction costs involved in the public purchase through the bidding process, there is a need for a simplification of Equation 1 to conduct the statistical tests. So:

Pbid $<$ Pm

According to Herrmann (1999) it is necessary to note that Equation 2 does not imply the absence of transaction costs. These remain present in the relationship of inequality between the two variables. Thus, for the transaction through the bidding be considered efficient, Pbid must be significantly lower than $\mathrm{Pm}$, and equality between the two is no longer acceptable. 
Eight electronic auctions were analyzed in the price registration system comprising the years 2014 to 2017 of the following items: mineral supplement, bovine mineral supplement, piglets ration for 7 and 35 days, piglets ration for 50 and 70 days, pig rearing ration for 71 and 110 days, pig termination ration, ration for gestating sows, ration for lactating sows, pelleted ration for rabbit, initial ration for chicken $20 \%$, initial ration for chicken $17 \%$, poultry ration, ration for lactating cow, dry cow ration, pellet ration for calves, pelleted ration for heifers, fertilizer formula NPK 8.28.16, fertilizer formula NPK 30.0.20, chemical fertilizer, physical appearance powder, chemical fertilizer, nitrogen and hybrid corn seeds. These purchases moved $\mathrm{R} \$ 2,806,307.85$.

To obtain market prices, the public administration used the price averages of three companies that supply agricultural products. Subsequently, by means of a statistical analysis, the initial values obtained from the market were compared with the bidding prices.

The data of the purchases were compiled initially in excel file (.xls), and later the data were submitted to the descriptive statistical analysis. Graphs and tables were used to compute the absolute and percent discount frequencies, in order to extract information from the sample studied. To sum up and analyze quantitative data, we used the boxplot graph, showing the central non-parametric trend, dispersion, and symmetry of the sample (Valladares et al., 2017).

\section{Results and discussion}

Tables 1 and 2 show the results obtained by IFSULDEMINAS - Campus Inconfidentes, in purchasing processes in the electronic auction mode Prices Registration System (RPS) of rations and supplements (Table 1 ) and fertilizers and seeds (Table 2).

The information in each column refers to:

Market Value $(\mathrm{Vm})$ : represents the maximum value to be paid by Public Administration, obtained through market research with the companies supplying agricultural inputs.

$\checkmark$ Bidding Value (Vbid): is the lowest value offered by one of the bidders, understood as the best offer at the end of the bids round with the auctioneer designated for the session;

The Economy column was divided into two parts:

$\checkmark$ The concept $V_{1}=(V m)-(V b i d)$ represents the economy obtained by the difference between the Market Value and the Bidding Value;

$\checkmark$ The concept $V_{2}=(V m)-(V b i d)$ represents the economy obtained by the difference between the Market Value and the Bidding Value, in percentage;

Table 1. Results of Electronic Auction - Ration and Agricultural supplements.

\begin{tabular}{|c|c|c|c|c|}
\hline \multirow{3}{*}{ Year } & \multirow{3}{*}{$\begin{array}{l}\text { Market value } \\
\quad(\mathrm{Vm})\end{array}$} & \multirow{3}{*}{$\begin{array}{c}\text { Bidding Value } \\
\text { (Vb) }\end{array}$} & \multicolumn{2}{|c|}{ Economy } \\
\hline & & & $\mathbf{R} \$$ & $\%$ \\
\hline & & & $V_{1}=V m-V b$ & $V_{2}=(\mathrm{Vm} / \mathrm{Vb})^{*} 100$ \\
\hline 2014 & $\mathrm{R} \$ 815,354.60$ & $\mathrm{R} \$ 633,273.10$ & $\mathrm{R} \$ 182,081.50$ & $22.33 \%$ \\
\hline 2015 & $\mathrm{R} \$ 791,916.90$ & $\mathrm{R} \$ 657,698.60$ & $\mathrm{R} \$ 134,218.30$ & $16.95 \%$ \\
\hline 2016 & $\mathrm{R} \$ 889,700.60$ & $\mathrm{R} \$ 701,580.80$ & $\mathrm{R} \$ 188,119.80$ & $21.14 \%$ \\
\hline 2017 & $\mathrm{R} \$ 1,072,581.20$ & $\mathrm{R} \$ 620,937.00$ & $\mathrm{R} \$ 451,644.20$ & $42.11 \%$ \\
\hline Total & $R \$ 3,569,553.30$ & $R \$ 2,613,489.50$ & $R \$ 956,063.80$ & \\
\hline
\end{tabular}

Source: Prepared by the authors. 
The information in each column refers to:

$\checkmark$ Market Value $(\mathrm{Vm})$ : represents the maximum value payable by the Public Administration, obtained through market research with the suppliers of agricultural inputs.

$\checkmark$ Bidding Value (Vbid): is the lowest value offered by one of the bidders, understood as the best offer at the end of the bids round with the auctioneer designated for the session;

Table 2. Results of Electronic Auction - Fertilizers and Seeds.

\begin{tabular}{cccccc}
\hline \multirow{2}{*}{ Year } & \multirow{2}{*}{$\begin{array}{c}\text { Market value } \\
(\mathbf{V m})\end{array}$} & \multirow{2}{*}{$\begin{array}{c}\text { Bidding Value } \\
(\mathbf{V b})\end{array}$} & & \multicolumn{2}{c}{ Economy } \\
\cline { 4 - 5 } & & & $\mathbf{V}=\mathbf{V m}-\mathbf{V b}$ & $\mathbf{V}=\mathbf{( V m} / \mathbf{V b})^{*} \mathbf{1 0 0}$ \\
\hline $\mathbf{2 0 1 4}$ & $\mathrm{R} \$ 42,008.40$ & $\mathrm{R} \$ 37,812.25$ & $\mathrm{R} \$ 4,196.15$ & $9.98 \%$ \\
\hline $\mathbf{2 0 1 5}$ & $\mathrm{R} \$ 18,534.75$ & $\mathrm{R} \$ 17,241.50$ & $\mathrm{R} \$ 1,293.25$ & $6.98 \%$ \\
\hline $\mathbf{2 0 1 6}$ & $\mathrm{R} \$ 65,522.10$ & $\mathrm{R} \$ 59,789.00$ & $\mathrm{R} \$ 5,733.10$ & $8.75 \%$ \\
\hline $\mathbf{2 0 1 7}$ & $\mathrm{R} \$ 135,418.30$ & $\mathrm{R} \$ \mathbf{7 7}, 975.60$ & $\mathrm{R} \$ 57,442.70$ & $42.42 \%$ \\
\hline Total & $\mathbf{R} \mathbf{2 6 1 , 4 8 3 . 5 5}$ & $\mathbf{R} \$ \mathbf{1 9 2 , 8 1 8 . 3 5}$ & $\mathbf{R} \$ \mathbf{6 4 , 4 6 9 . 0 5}$ & \\
\hline
\end{tabular}

Source: Prepared by the authors.

The Economy column was divided into two parts:

$\checkmark$ The concept $V_{1}=(\mathrm{Vm})-(\mathrm{Vbid})$ represents the economy obtained by the difference between the Market Value and the Bidding Value;

$\checkmark$ The concept $V_{2}=(V m)-(V b i d)$ represents the economy obtained by the difference between the Market Value and the Bidding Value, in percentage;

In the comparison between the prices paid by IFSULDEMINAS Campus Inconfidentes in the purchase of rations and agricultural supplements and the market prices, we observed that savings occurred between the observed years and the year 2015 had the lowest percentage of $16.95 \%$, already in 2017 , the highest percentage was observed, being $42.11 \%$, as shown in table 01 . Regarding to the acquisition of fertilizers and seeds we observed that the year 2015 obtained the lowest discount percentage $6.98 \%$ and the year 2017 with the highest percentage $42.42 \%$, see Table 2 .

To analyze the data regarding transaction costs for suppliers, it should be noted that the biddings investigated here are in the price registration system, where the company must keep the bidding price for the maximum period of 12 months according to the signature of the prices record, for installments delivered during the year, according to delivery schedules. As stated by Justen (2005) transaction costs acquire enormous relevance as a theoretical tool to guide public administration in structuring and conducting the bidding, thus obtaining the most advantageous proposals, which can be observed in Table 3.

Electronic Auctions within federal public agencies reduce the transaction costs of participating companies by influencing the cost of their proposals. The agency object of this study uses the portal Government Purchases - Comprasnet, the federal government procurement portal, has generated significant savings for the federal government according to Table 3.

This bidding method performed by Comprasnet site allows greater transparency in the bidding, where any citizen can follow the steps of acceptance, qualification, homologation, award and exchange of messages between the auctioneer and the 
suppliers, also allows agility in the process where only the documents related with qualification of the winning company are analyzed, with respect to competitiveness, the system allows the suppliers to track what the lowest price is, if their price is tied, if it is above the estimated, improving the competitiveness among companies.

According to Ricci \& Nakao (2006) the trading is widely spread, including the internet, and participation is open to any interested person. Simplification can stimulate increase competitiveness and expand the participation of small and medium-sized enterprises, benefiting from reduced transaction costs. For a small business to follow the disclosure in newspapers or official journals and communicate with the interested agency by telephone, it can often make the business unfeasible. With the increase in the number of competitors, prices tend to fall.

Table 3. Percentage discount statistics per item between 2014 and 2017.

\begin{tabular}{ccccc}
\hline \multicolumn{5}{c}{ Fertilizers and Seeds } \\
\hline Mininum & $\mathbf{1}^{\text {st }}$ Quartile & Median & $\mathbf{3}^{\text {rd }}$ Quartil & Maximum \\
\hline 0.00 & 0.25 & 10.09 & 20.91 & 47.86 \\
\hline \multicolumn{5}{c}{ Rations and Supplements } \\
\hline Minimum & $\mathbf{1}^{\text {st }}$ Quartile & Median & $\mathbf{3}^{\text {rd }}$ Quartil & Maximum \\
\hline 0.00 & 14.08 & 21.61 & 37.14 & 52.32 \\
\hline
\end{tabular}

Source: Prepared by the authors.

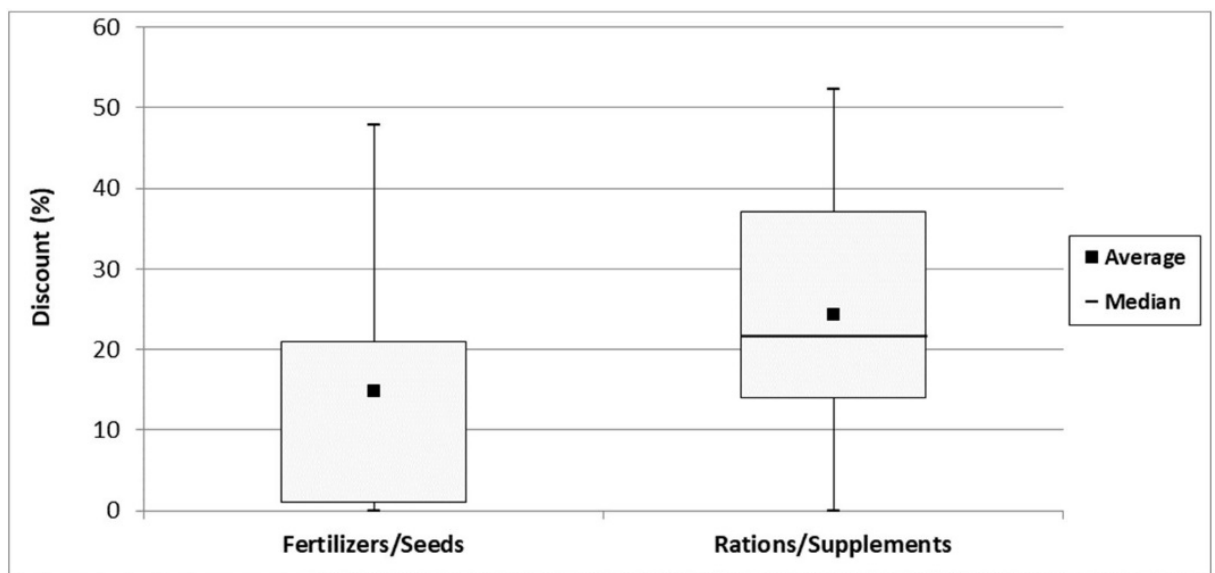

Figure 1. Percentage discount statistics per item between 2014 and 2017. Source: Prepared by the authors.

When analyzing Figure 1 we observe referring to the acquisition of rations and supplements that on average the discount percentage was around $24.29 \%$, but some products did not present any discount and others with discounts of up to $52.32 \%$. According to Silva (2011) opportunistic behaviors rarely involve lies, theft or cheating, for the author the opportunism is linked to the supply of incomplete or distorted information, generating a situation of information asymmetry among the contractors, which may explain these discount percentages above $50 \%$ for some items.

The precise definition of the object, the establishment of the contract management structure, the selection of contractual guarantees and the formation of prices are all interactive elements, and must be determined simultaneously as reported by Silva 
(2011), based on the data presented, it is possible to affirm that these procedures did not occur completely in the acquisition of rations and supplements.

Yet in Figure 1 referring to the acquisition of fertilizers and seeds on average the discount percentage was around $14.74 \%$, with some items without discount and others with discounts of up to $47.86 \%$. The biddings of rations and supplements obtained a greater discount in comparison with purchases of fertilizers and seeds, $50 \%$ of the items related to rations and supplements obtained discounts between $14.08 \%$ and $37.14 \%$, already fertilizers and seeds with $50 \%$ of the items with discounts between $0.25 \%$ and $20.91 \%$, this is due to transaction costs and a greater degree of uncertainty regarding the products as fertilizers that are largely imported.

According to Valladares Neto et al. (2017) analyzing Figure 1, it is possible to affirm that the data do not present normal distribution, since the values of arithmetic averages and medians are not close. Based on this information, it can be observed that the discounts vary from item to item, we can cite how it justifies this variation for items as reported by Fiuza (2009) where in addition to the transaction costs incurred directly by the purchasing agency, it is worth noting that there are also those incurred by the suppliers, which are passed on to the prices charged.

Figure 2 shows the variation of quoted prices in the market and the price variation in the Electronic Auction of both fertilizers and seeds and rations and supplements. With this, we observed that market prices in the quotation are higher than prices in the electronic auction, that is, the bidding process in the electronic auction modality allows a price difference between the items when compared with the market prices. This fact is explained in Oura et al. (2012), in which companies can substantially burden the values in the preparation phase of the bidding, in order to obtain additional profits when the bidding process occurs, that is, the companies that provide reference price budgets participate in the bidding contest offering prices below the estimated value, this fact is credited to the opportunism of the bidder, or the supplier.

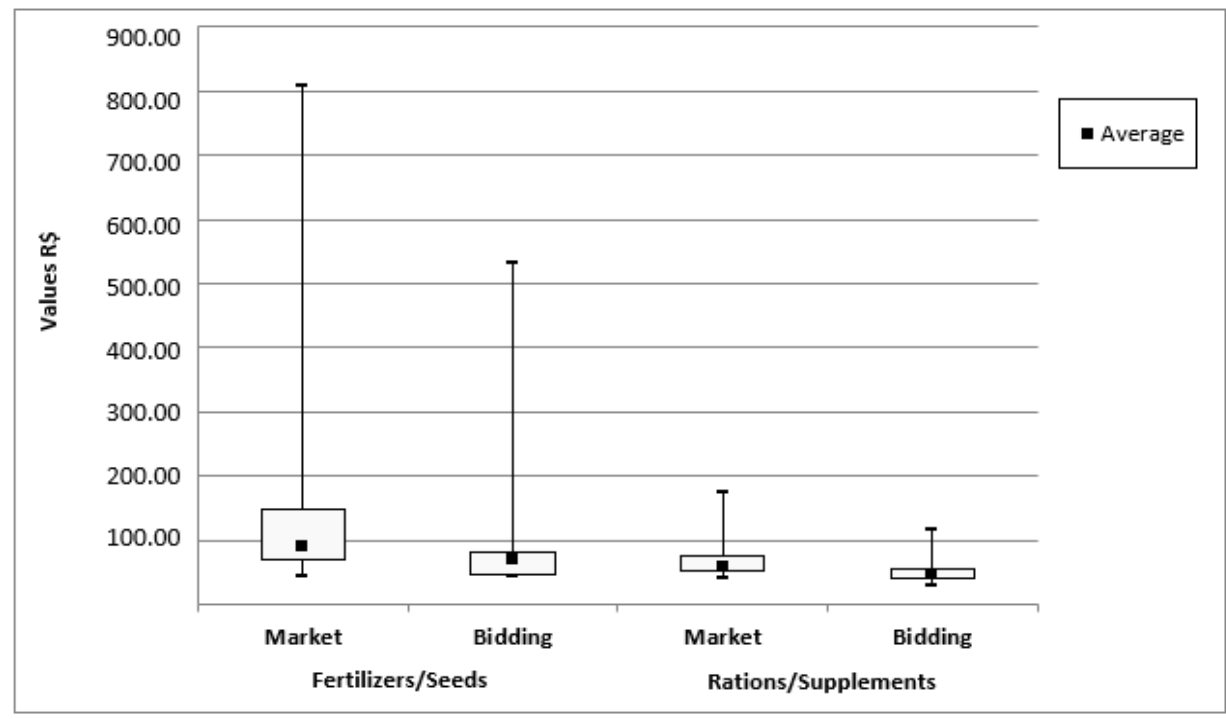

Figure 2. Comparative market and bidding prices between 2014 and 2017. Source: Prepared by the authors. 
As stated by Faria et al. (2010), most suppliers seek to increase the frequency of transactions by creating more favorable pricing policies for known public agencies, the frequency of transactions is also advantageous for the bidder, since the accumulation of information on the bidder agency allows the reduction of costs associated with the unpredictability of the negotiation, inducing a lower price to gain competition.

They are costs with registration, obtaining certificates, conducting tests, producing samples, filing legal appeals, personnel displacement needs, as well as freight, and taxes. For Fiuza (2009) the more bureaucratic procedures, and the greater the uncertainty about the conclusion of the purchase process, the greater the costs of the firms participating in the bidding.

Despite problems in some items in the markets studied, we can affirm that the electronic auction softens transaction costs, Oliveira \& Santos (2016) report that a transaction will be efficient when it minimizes transaction costs, which is partially achieved through electronic auctions.

\section{Final considerations}

This article sought, from the information and data collected with IFSULDEMINAS Campus Inconfidentes, to verify the interference of transaction costs in the formation of the reference value, in the behavior of suppliers regarding to discounts in the biddings made through electronic auction in purchases made by the Campus of agricultural inputs.

We verified that there was an economy in the biddings between the years 2014 and 2017, that the electronic auctions in the scope of federal public agencies soften the transaction costs of the participating companies influencing in the cost of their proposals, the notices, price registration system and contracts of the agency under study have clauses as complete as possible: such as delivery time, delivery schedule, sanctions, penalties, payment term, price adjustment, in order to reduce the uncertainties of the participants, which affects the price offered.

However, discounts were observed above $50 \%$, which leads us to believe in the case of the biddings under study, that the participants acted with opportunism, in items in which the public agency under study did not fully specify the bidding product, we also have situations where companies participating in the price survey to determine a reference value, they act with opportunism raising the costs of the goods, leaving their best offer to the bid stage when the bidding occurs.

Thus, suppliers can take advantage of this incompleteness of material specification to quote products of lower quality or that do not meet the needs of the buyer or overvalue the prices and then negotiate in the dispute with the competitors during the bidding. It is clear that it is up to government to include in the planning of contracts and acquisitions theories of transaction costs, thus improving the conduct of public purchase.

In general, it is concluded that the transaction costs of the suppliers are reduced due to the dispute with the competitors in repetition of bids, the well-drafted clauses in the bidding edicts and contracts that reduce the uncertainties, a reduction in acquisitions is already taking place for the purchasing agencies, since the repetition of bids on the electronic auctions forces the price reduction by the suppliers. 


\section{References}

Braga, E. (2006). Inovações recentes no sistema de compras do Governo Federal. Retrieved in 2017, October 29, from www.enap.gov.br

Brasil. (1993). Lei no 8.666, de 21 de Junho de 1993. Regulamenta o art. 37, inciso XXI, da Constituição Federal, institui normas para licitações e contratos da Administração Pública e dá outras providências. Brasília, DF: Diário Oficial da República Federativa do Brasil. Retrieved in 2017, October 28, from http://www.planalto.gov.br/ccivil_03/Leis/L8666cons.htm

Brasil. (2002). Lei $n^{\circ} 10.520$, de 17 julho de 2002. Institui, no âmbito da União, Estados, Distrito Federal e Municípios, nos termos do art. 37, inciso XXI, da Constituição Federal, modalidade de licitação denominada pregão, para aquisição de bens e serviços comuns, e dá outras providências. Brasília, DF: Diário Oficial da República Federativa do Brasil. Retrieved in 2017, October 29, from http://www.planalto.gov.br/ccivil_03/leis/2002//10520.htm

Faria, E. R., Ferreira, M. A. M., \& Gonçalves, M. A. (2013). Avaliação dos Riscos do Pregão Eletrônico: uma abordagem pela Teoria da Nova Economia Institucional. Revista de Ciências da Administração, 15(37), 211-227. http://dx.doi.org/10.5007/21758077.2013v15n37p211.

Faria, E. R., Ferreira, M. A. M., Santos, L. M. A., \& Abrantes, L. A. (2010). Aspectos transacionais e comportamentais dos agentes no Pregão Eletrônico: um enfoque na administração pública. Revista de Economia e Administração, 9(2), 151-169. http://dx.doi.org/10.11132/rea.2009.267.

Fiani, R. (2013). Teoria dos custos de transação. In D. Kupfer \& L. Hasenclever. Economia industrial: fundamentos teóricos e práticas no Brasil (2. ed., Cap. 13, pp. 171-181). Rio de Janeiro: Elsevier. http://dx.doi.org/10.1016/B978-85-352-6368-8.00013-X.

Fiuza, E. P. S. (2009). Licitações e governança de contratos: a visão dos economistas. In L. H Salgado \& E. P. S. Fiuza (Org.), Marcos Regulatórios no Brasil: É tempo de rever regras? (pp. 239-274). Rio de Janeiro: IPEA.

Hasenclever, L., \& Kupfer, D. J. (2012). Economia industrial. Rio de Janeiro: Elsevier.

Herrmann, I. (1999). Licitações públicas no Brasil: explorando o conceito de ineficiência por desenho. Revista ADM, 34(2), 29-38.

Horn, M. J. (2002). Political economy of public administration: institutional choice in the public sector. Cambridge: Cambridge University Press. (Political Economy of Institutions and Decisions).

Izaac, N. R., Fo., \& Biderman, C. (2005). Sistema de Compras Eletrônicas por Leilão Reverso: Estudo dos Impactos Observados na Experiência do Estado de São Paulo. In Anais do XIX EnAnpad. Brasília: EnAnpad.

Justen, M., Fo. (2005). Comentários à lei de licitações e contratos administrativos (11. ed.). São Paulo: Dialética.

Lamarão, R. C. (2011). Os custos de transação do contrato administrativo derivado de licitação: uma incidência da teoria da imprevisão. Revista Direito em (dis)curso, 4(2), 11-21.

Lopes, A. E. M. P. (2017). Dependência de recursos e custos de transação: rumo a um modelo convergente. Gestão \& Produção, 24(4), 806-813. http://dx.doi.org/10.1590/0104$530 \times 2819-16$.

McAfee, R. P., \& McMillan, J. (1987). Auctions and bidding. Journal of Economic Literature, 25(2), 699-738.

Menezes, R. A., Silva, R. B., \& Linhares, A. (2007). Leilões eletrônicos reversos multiatributo: uma abordagem de decisão multicritério aplicada às compras públicas brasileiras. Revista de Administração Contemporânea, 11(3), 11-33. http://dx.doi.org/10.1590/S141565552007000300002. 
Nóbrega, M. (2009). Contratos incompletos e infraestrutura: contratos administrativos, concessões de serviços e PPPs. Revista Eletrônica de Direito Administrativo Econômico, $18,1-17$.

Oliveira, N. J., Jr., \& Santos, E. A. (2016). A necessidade de conhecimentos específicos para o fiel cumprimento do acompanhamento e fiscalização de contratos no âmbito da administração pública segundo o disposto no art. 67 da Lei n ${ }^{\circ} 8.666 / 93$. Revista de Administração de Roraima-RARR, 6(2), 500-519. http://dx.doi.org/10.18227/22378057rarr.v6i2.3517.

Oura, M. M., Kono, C. M., Rodrigues, L. C., \& Riccio, É. L. (2012). O pregão eletrônico como instrumento de controle de oportunismos no processo licitatório público. Revista de Gestão e Projetos - GeP, 3(2), 260-281. http://dx.doi.org/10.5585/gep.v3i2.118.

Padilha, A., Araújo, E. C., \& Souza, J. P. (2018). Influência das incertezas nas contratações públicas por intermédio do pregão eletrônico. Revista Brasileira de Planejamento e Desenvolvimento, 7(1), 67-84. http://dx.doi.org/10.3895/rbpd.v7n1.7127.

Peres, U. D. (2007). Custos de transação e estrutura de governança no setor público. RBGN, 9(24), 15-30.

Ricci, M. A. D., \& Nakao, S. H. (2006). Um estudo sobre leilão inglês reverso, contabilidade de custos e decisões: os pregões governamentais. In Anais do XIII Congresso Brasileiro de Custos. Belo Horizonte: ABC.

Sarto, V. H. R., \& Almeida, L. T. (2015). A teoria dos custos de transação: uma análise a partir das críticas evolucionistas. Revista Iniciativa Econômica, 2(1), 1-25.

Schlabitz, C. J. (2008). Custo de transação e o mercado de crédito brasileiro: uma análise sob a ótica da nova economia institucional (Dissertação de mestrado). Programa de Pósgraduação em Economia, Universidade Federal do Rio Grande do Sul, Porto Alegre.

Silva, C. A. D. (2011). A Contratação de Serviços Complexos pela Administração Pública. Revista Jurídica da Procuradoria Geral do Estado do Paraná, 49-72.

Valladares, J., No., Santos, C. B., Torres, É. M., \& Estrela, C. (2017). BOXPLOT: um recurso gráfico para a análise e interpretação de dados quantitativos. Revista Odontológica do Brasil-central, 26(78), 1-6.

Vasconcelos, F. (2005). Licitação Pública: análise dos aspectos relevantes do Pregão. Retrieved in 2017, October 29, from http://periodicos.ufpb.br/index.php/prim afacie/article/view /4 56 6/3436

Williamson, O. E. (1985). The economic institutions of capitalism. New York: Free Press.

Zylbersztajn, D. (2005). Papel dos contratos na coordenação agro-industrial: um olhar além dos mercados. Revista de Economia e Sociologia Rural, 43(3), 385-420. http://dx.doi.org/10.1590/S0103-20032005000300001. 